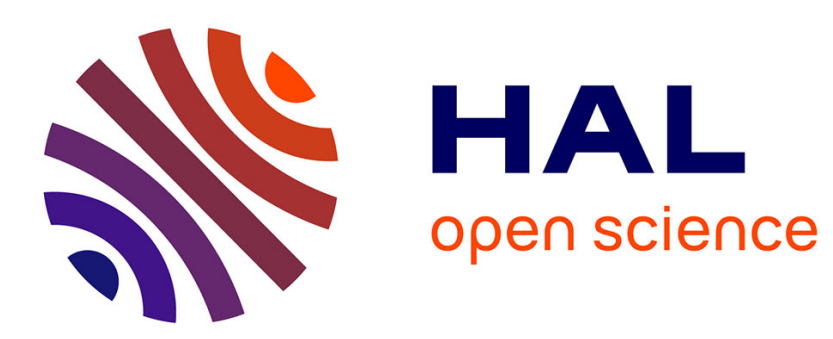

\title{
Europe as a missed opportunity
}

Géraldine Bozec, Sophie Duchesne

\section{To cite this version:}

Géraldine Bozec, Sophie Duchesne. Europe as a missed opportunity: Looking backwards to modernity in France. Atsuko Ichijo. Europe, Nations and Modernity, Palgrave Macmillan, pp.37-59, 2011, Identities and Modernities in Europe, 9780230301436. halshs-00652467

\section{HAL Id: halshs-00652467 https://shs.hal.science/halshs-00652467}

Submitted on 15 Dec 2011

HAL is a multi-disciplinary open access archive for the deposit and dissemination of scientific research documents, whether they are published or not. The documents may come from teaching and research institutions in France or abroad, or from public or private research centers.
L'archive ouverte pluridisciplinaire HAL, est destinée au dépôt et à la diffusion de documents scientifiques de niveau recherche, publiés ou non, émanant des établissements d'enseignement et de recherche français ou étrangers, des laboratoires publics ou privés. 


\section{Europe as a missed opportunity: looking backwards to modernity in France.}

Géraldine Bozec \& Sophie Duchesne, Sciences Po

IME book chapter proposal on Europe and modernity (the French case) - Dec. 2010

It is widely acknowledged than in northern European countries, France included, the route to modernity was paved with nationalism, and that along the way, these nations were established as the secular, democratic, industrialised (and eventually post industrialised) welfare states we know today (Greenfeld 1992; Hobsbawm 1992). However, each of these countries took their own route to modernity, and experienced the tensions inherent in this process in their own way. Moreover, we know from previous work that European integration is "framed" by national culture; it is thus perceived differently in different European countries (Diez Medrano 2003). Has the specificity of France's route to modernity had an impact on the way the French have perceived Europe? More specifically, has it affected European integration and the possible generation of a corresponding identity?

Addressing these questions means first providing a brief overview of the specificities of the French route to modernity, with an emphasis on the tensions that it was born out of. We will move on to an account of the limited and ambiguous ways in which intellectuals have explicitly referred to modernity in their discussions of Europe over the last century. In the third section, we will focus on the role of political debate, showing how a range of issues, positions and divisions have been reduced to a single choice between being "pro" or "anti" Europe. We will conclude by addressing the consequences of this limited debate concerning France's European future, its impact on French citizens' attitudes towards their new political community, and the "missed opportunity" that this lack of debate represents ${ }^{1}$.

\section{1) The French route to modernity: specific features}

The literature on modernity generally takes a broad theoretical approach to this notion, and even in France tends to focus on Western societies in general, rather than closely examining the specificities of the French case (Boisvert 1996; Bonny 2004; Freitag 2002; Javeau 2007; Lipovetski 2004; Lyotard 1979; Maffesoli 2000; for an exception focused on the French route to political modernity, see Barbier 2000). However, there are authors who explicitly refer to the concepts of modernity and modernisation when studying specific aspects of French history (especially economic development, state-building, religion and secularism).

Most authors begin by agreeing on the centrality of the French Revolution in the emergence and development of modernity in France. Although certain continuities between the French Revolution and the monarchy that preceded it are commonly emphasised

\footnotetext{
${ }^{1}$ Many thanks to our colleagues of the IME consortium for discussing the report on which this paper is based, as well as Nuria Garcia for her suggestions. Special thanks to Katharine Throssell who helped revise the final version.
} 
(especially regarding the centralisation of the state before and after the revolution, see below), it is still broadly considered a key turning point because it implemented the central claims of the Enlightenment. Individual rights were declared universal and political sovereignty and legitimacy were transferred from the monarch to the nation, defined as a community of citizens. The revolution gave rise to the idealised figure of the citizen: an abstract individual who must detach him or herself from their particular interests and sub-national identities (religion, social class and so on) to enter the public sphere (Schnapper 1994, 2000; Rosanvallon 1992). The French Revolution is considered the origin of the universalist and individualist vision of the nation and citizenship, and the source of a specific tradition that continues to run deep in contemporary French political culture (Krulic 2007).

However, the route to modernity in France was no more linear and univocal than in any other country (Eisenstadt 2000; Arnason 2003). According to Barbier (2000), the long and difficult implementation of political modernity in France was mainly due to the weight of the monarchy and the aristocracy in the nation's past; compared to the United States, for example, which embarked directly on political modernity when it became a fully autonomous state. The $19^{\text {th }}$ century in France was marked by instability and recurrent restoration of regimes opposed to the democratic principles of the revolution (monarchies and Empires). Moreover, throughout the $19^{\text {th }}$ and the $20^{\text {th }}$ centuries, various political movements remained vehemently critical of the modernity represented by the French Revolution. These voices of criticism included the counter-revolutionary ideology of de Maistre (late $18^{\text {th }}-$ early $19^{\text {th }}$ centuries); the nationalist ideology of Barrès or Maurras (late $19^{\text {th }}$ - early $20^{\text {th }}$ centuries); the ideology of the Vichy regime (1940-1944); and the political thought of the National Front (since the 1980s). In spite of their significant differences, these movements have defended a vision of the French nation that is both organic and natural, based on the perpetuation of age-old traditions and the maintenance of ethnic homogeneity (Birnbaum 1991; Winock 2004). Some of them also emphasised the role of Catholicism in French national identity, and the image of France as the 'eldest daughter' of the Catholic Church.

Republican theorists were not homogeneous in their perspectives either, however, instead demonstrating a range of conceptions of the nation and citizenship (Déloye 1994; Rosanvallon 1992). Some republicans insisted on the principles of the Enlightenment, centring their vision on a contractual, universalistic, and individualistic conception of the nation; in which the individual's commitment to the national community, their willpower and rational thought were central. Other republicans demonstrated a more communitarian conception. Without defining the nation as a closed ethnic community (unlike right-wing nationalist movements), they awarded more importance to the idea that individuals are inexorably anchored in their national community, and that the nation is a salient category that has evolved out of a long shared history.

Another related dimension of the French political struggle of the $19^{\text {th }}$ and $20^{\text {th }}$ centuries, much discussed in the literature, is the long-lasting conflict between Catholics and republicans (Baubérot 1990; Birnbaum 1993; Déloye 1994; Hervieu-Léger, 2003). This confrontational relationship is more than a power struggle between two centralised and highly influential institutions; it is also connected to the historical symbiosis of the $18^{\text {th }}$ and $19^{\text {th }}$ centuries; between the Catholic religion and the pre-revolutionary order of the Ancien Regime - and thus also the monarchist cause. This confrontation eventually led to a specific institutional 
arrangement, settled during the late $19^{\text {th }}$ and the $20^{\text {th }}$ centuries in the form of the French principle of 'laïcité'. This scarcely translatable concept was the result of the intentional obligatory secularisation of public institutions (Hervieu-Léger 2003); it corresponds to a particularly high degree of separation between religion and the state (Baubérot 2006). Over time, Catholics have rallied to the Republic and to the principle of laïcité, although French history has continued to be marked by successive compromises on both sides (Baubérot 1990; Mayeur 1997).

Despite the advent of secularism and the decline of the social and institutional influence of the church over the course of the $20^{\text {th }}$ century, Catholicism nevertheless continues to play a significant role within French modernity. Both Hervieu-Léger (2003) and Birnbaum (2003) argue, in different ways, that there are affinities between Catholicism and French republicanism. Hervieu-Léger points out the analogies between the institutional arrangement of the Catholic religion and the organisation of the republican state in France. Like the Catholic Church, the French republican state system is hierarchical, centralised and territorialised; the authority figure of the republican teacher mirrors that of the priest; and the way republicanism conceives the 'community of citizens', insisting on unity and harmony, resembles the image of the community of the faithful in Catholicism. According to Birnbaum, the 'French exception' is essentially in the emphasis on cultural unification - be it based on Catholic principles or republican ones.

Overall, the long struggles between revolutionary and counter-revolutionary forces, the conflict between Catholics and republicans, and the plurality and tensions within republicanism itself, have all contributed to a vision of the French nation wrought with internal conflict. According to this vision, France is seen as both universalist (born out of the revolution and empowered by Enlightenment values) and unique (steeped in a past considered singularly immemorial and glorious). The tension between these two faces of French national identity, inherited by most citizens (Duchesne 1997), has clearly been reactivated in the last decade both by intellectuals and in political discourse (Laborde 2010; Hayward 2007). This was particularly obvious during the so-called "debate on national identity" called for by President Nicolas Sarkozy, and organised by the government in autumn 2009.

This debate, and the way it was launched by the government, underlines another inherited feature of the French route to modernity: the centrality of the state, and the strength and legitimacy of its unifying mission. This is seen as the result of the highly developed feudalism that existed in France, which enabled the monarchy to concentrate its power and unify the national territory by force. By contrast, feudalism in England was less fragmented, and political centralisation was achieved earlier through the mechanisms enabling representation of territorial and social peripheries (Badie and Birnbaum 1979; Birnbaum 1993). This process of centralisation by the state was accentuated in France from the French Revolution onwards. A large state bureaucracy was set up in the $19^{\text {th }}$ and $20^{\text {th }}$ centuries, and its numerous staff were trained in prestigious state educational institutions. From the late $19^{\text {th }}$ century onwards, the public school system was expanded and eventually made compulsory, contributing both to the homogenisation of national values and the standardisation of the French language (Peres 1994; Weber 1983). After 1945, the centralisation of the state continued with the development of welfare state policies and state organised economy. 
The perceived supremacy of the state and its unifying mission had two major consequences that shaped the French route to modernity. Firstly, counter-state forces (mainly the Catholic Church and trade-unionism) developed in a particularly confrontational way in France (Birnbaum 1993); anarcho-syndicalism (inspired notably by Proudhon's thought), which is explicitly an anti-state unionism, was particularly strong for example. Secondly, the dominant and homogenising role of the state resulted in a weak organised civil society. In comparison with most other Western democracies, local organisations, associations and all kinds of intermediate structures, supposed to bring life to the public sphere, have remained weak in France (Archambault \& Boumendil 1999; Barthélémy, 2000; Simonet, 1998). The historical importance of unity in France goes some way to explaining that pluralism in society remains difficult to acknowledge, and that little room is made for the expression of diversity. In particular, this accent on unity accounts for the historic struggle against regional languages in French public primary schools in the first part of the $20^{\text {th }}$ century (Weber 1983; Chanet 1996), but also for the more recent debates surrounding France's signature of the European Charter for Regional or Minority Languages. It also accounts for the difficult accommodation of the cultural diversity related to immigration in recent decades and to the presence of a large Muslim community in France. Pluralism and diversity conflict with both aspects of the French imagined community (Duchesne 2005): both with its universalistic aspirations on one hand (Schnapper 1994), and its nostalgic belief in a unique historical identity (Thiesse 2010).

Up until the 1960s-1970s, the idea of France as a model of modernity was common in the social sciences literature. France was often presented as a precocious nation-state (and democracy) with a universalistic message that was a model for other nations. France's universalism was sometimes emphasised in a way that overlooked the fact that their allegedly "universal" values were in fact simply French. Nevertheless, over the last thirty years, a critical view of French history and its ethnocentric trends has been developing in the literature. This critical approach deconstructs the 'national myth' built by historians and state elites (Citron 2008) and conveyed to French citizens through education (Bozec 2010). It highlights forms of oppression that are an integral part of French history (Citron 2008; Noiriel 2006, 2007). This critical stance goes hand in hand with the push for a plural narrative of history; one which takes into account the importance of cultural diversity, and pays attention to processes of domination, notably those related to colonisation (Blanchard et al 2005).

The key features of the specific French route to modernity can thus be summarised as follows: the decisive impact of the revolution; the permanent tension between universalism and a sense of immemorial identity within the conception of the nation; the persistent impact of the antagonism between Catholicism and republicanism; the central role of the state, its supremacy over civil society and its unifying mission; and, as a consequence of this mission, France's difficult relationship with pluralism. How has this combination of factors influenced the way European unification has been perceived in France over the last century? More specifically, has it been experienced as a new step towards modernity or not? To address these questions we will look at French discourses on Europe since WWI - from intellectuals (Section 2) and political actors (Section 3), exploring the ways they have referred to modernity (or not). 


\section{2) Europe and modernity in French intellectual discourses since WWI: from engagement to lack of interest or criticism}

Since the First World War, some French intellectuals have seen European unification as a possible way of achieving a new political modernity; associating it with the ideas of peace, democracy, and the containment of the negative effects of nationalism. However, some also regard it as a means of fighting against Europe's decline. However, these positive perspectives on Europe were developed at specific points in time, mainly during and immediately after WWII. When European integration actually developed, from the 1950s onward, most French intellectuals turned away from Europe as a valuable route to a new modernity.

The Europeanist movement in France in the interwar years: European unification as a means of fighting against Europe's decline and the dangers of nationalism

Up until the Second World War, French authors made a significant contribution to reflections on European unification. French proposals for a united Europe can be traced back to the Middle Ages (du Réau 2001). From the $18^{\text {th }}$ century onwards, French thought about European unity was more and more connected to democratic principles and to the idea of peace - with the exception of Napoleon's attempt to unify Europe by force in the early $19^{\text {th }}$ century. During the second half of the $19^{\text {th }}$ century, the idea of European unity gained more ground and was advocated by various figures and movements, from promoters of free-trade to pacifists and socialists. However, the rise of nationalism between 1870 and 1914 slowed down the movement in favour of European unity. Moreover, internationalism, not limited in scope to the European continent, gained more and more influence in pacifist and socialist circles and tended to eclipse Europeanism (Dulphy \& Manigand 2006).

The First World War represented an important turning point. The shock of the war led to the emergence and development of a significant Europeanist movement, both in France and elsewhere in Europe. Although it developed mainly in the international circles of the League of Nations in Geneva (Dulphy \& Manigand 2006), the unification of Europe was then regarded as an important goal and was supported by specific organisations and journals, as well as by a European network of elites (Chabot 2005). French actors from both intellectual and economic circles took a significant role in this, and were supported by French politicians from the Radical party (the French centrist political movement, very influential during the Third Republic), the Christian-Democrats and the non-Marxist left.

An essential component of Europeanism during the interwar years was obviously a deep desire for peace. As noted by Bonneville (1961), pacifism led intellectuals to advocate the union of Europe and conversely, the credo in European unity required pacifism: they were inextricably linked. The feeling that a new war would lead to the self-destruction of Europe was a significant aspect of Europeanism during this period.

European activists also worried about what they considered to be the decline of European civilisation. French intellectuals, as well as those from other parts of Europe, expressed a profoundly pessimistic vision. They emphasised the idea of a spiritual and moral crisis 
generated by the war, as well as the general loss of Christian values and the new rise of materialism. Materialism, often associated with American culture, was considered to be developing at the expense of intellect, which was seen as a specific feature of European civilisation. Chabot shows that some Europeanist intellectuals in France, such as the columnist Gaston Riou or the philosopher Julien Benda, saw European unification as a means of regenerating Europe, both spiritually and morally. For these thinkers, the idea of Europe was charged with religious meaning.

The unification of Europe was thus also seen as a means of challenging political ideology, particularly nationalism and to a lesser extent Soviet communism (Chabot, 2005). Although some French intellectuals tended to see the future united Europe as a nation, this European 'nation' was perceived as potentially countering the negative effects of nationalism. According to Julien Benda, who published his Discours à la nation européenne (speech to the European nation) in 1933, the future European nation would be less 'impious' than current nations since it would create a less solid, exclusive, and affective link between individuals and their territory. Benda assimilated Europe to the victory of rationality, universalism, and abstraction. His perspective is ambiguous, however, because the desired Europe was implicitly to take the form of the French 'hexagon' (Lacroix 2008; Müller 2006): the common language for Europe would necessarily have been French, since he believed it to be the most rational language, and Europe's universalism was identified with France - and opposed to Germany's particularism.

Although relayed by one prominent French political figure, Aristide Briand, from the mid1920s to the early 1930s, the Europeanist movement failed because of the divergences both between and within nations, and above all, because of the climate of economic crisis and the international tensions of the 1930s. The 'intellectualism' of the Europeanist movement was another element that played a role in the failure of the European idea in the interwar years (Chabot 2005). Europeanism mainly came from intellectuals who believed in the power of thought, but their publications scarcely made an impact on public opinion.

Finally, let us not forget that if Europeanism was intended to favour peace, for French intellectuals it also represented a challenge to the economic and political rise of the United States and the waning of European power. The relationship with the United States was ambiguous, since it was simultaneously based on competition, on embodied materialistic values, on the rejection of a power that was making Europe its economic "vassal", and on the imitation of what was perceived to be an economic model (Chabot 2005; Bussière, Dumoulin 1998).

\section{Post-1950s European integration, accompanied by a decline in pro-active thought about Europe.}

Europeanism reappeared during the Second World War amongst members of the French Resistance and its socialist and Christian-democrat components in particular. This diffuse proEuropean feeling became true awareness after the discovery of the concentration camps. This triggered a general desire for peace and the rapprochement of peoples, ideas which were embodied in the very notion of European unification (Girault 1994). The immediate post-war period has much in common with the interwar years since there was a profusion of various 
Europeanist movements. Some post-1945 Europeanist figures had already been active in the Europeanist movement of the interwar years (du Réau 2001), but their voices had greater impact and led to greater concrete achievements after the war. However, given that the European initiative was essentially in the hands of state actors, the involvement of French intellectuals declined (du Réau 2001; Frank 2004b; de Puymège 1997).

Indeed, the period after 1945 is characterised by what Bachoud calls the 'European paradox of intellectuals'. After the 1950s, in the very period of the construction of European integration, only a few intellectuals put forward strong Europeanist convictions- in France as elsewhere (Bachoud, Cuesta, Trebitsch 2009). French prominent intellectual figures took part in the Congress of La Haye in 1948, but their enthusiasm for European unification declined shortly after. The Cold War marked a turning point, with the central issue becoming the need to take a stance on communism and the Soviet Union.

The strong influence of Marxism in intellectual circles in France is one of the key factors explaining why many French intellectuals considered European integration in a negative light (Girault 1994). In the 1960s, many of them saw Europe as the incarnation of the West at a time when they were engaged in fighting American and Western interests in support of the Third-World. Beyond Marxist intellectuals, many other French thinkers regarded the European Community as being too liberal economically and too technocratic - and still do today.

A more positive conception of Europe did emerge in the 1970s. The reception of Soljenitsyne's book The Gulag Archipelago in France provoked a limited revival of Europeanist thought amongst French intellectuals. At the time, Europe was more associated with the fight for freedom and democracy (Bachoud, Cuesta, Trebitsch 2009); the publication of the Manifesto of the 'Committee of Intellectuals for a Europe of freedoms' in 1978 is symbolic of this trend. This manifesto attracted support from diverse quarters, from Christiandemocrats, the non-Marxist left and liberals. Aside from this specific period, however, the European project did not attract that much attention from French intellectuals.

French writing on Europe reappeared in the 1990s and 2000s, but it was mainly reactive and provoked by EU institutional developments and policies, especially the controversies surrounding the Maastricht Treaty and then the Constitutional Treaty. According to Lacroix and Magnette (2008), over the last two decades, most French intellectuals have tended to focus on the future of democracy and nations in general. They do not thoroughly address the specific experience of European integration and do not see Europe as an object of intrinsic value for thinking about the future. When the EU is the specific object of analysis, it tends to be seen in a negative light and not as a potential political community.

Lacroix (2008) distinguishes three main paradigms in French political thought about Europe over the last twenty years. The first one - 'disincarnated Europe' - is predominant, taking the form of a denunciation of European construction on the grounds of the absence of a defined political body with a common past, shared boundaries and collective goals (which can provide citizens with a sense of identity and security). It brings together authors such as Pierre Manent, Marcel Gauchet or Paul Thibaud and is regularly expressed in major intellectual journals such as Le Débat or Commentaire. Some of these authors, however, try to combine the nation and Europe by continuing to emphasise the nation as the key political space, but also recognising a form of transnational power in the EU. 
The second paradigm - 'dreamt Europe' - is much less influential. This is a French version of the cosmopolitan perspective (inspired by Habermas) on Europe. According to Jean-Marc Ferry, one of the most important representatives of this trend, it is necessary to dissociate democracy and the nation-state because mastery of the future (especially of economic globalisation) is only possible at the European level. European identity must not be conceived of in substantial terms, since the very meaning of Europe is to be in a constant reflexive relationship with its past and traditions. The political integration of Europe is not only desirable, but is rendered possible by the development of horizontal links between Europeans and a juridical integration of national states.

The third paradigm - 'missed Europe' - mainly represented by Etienne Balibar, also sees the European project in a positive light: as a means of fostering individual rights, democracy, and the rejection of nationalism. However, there is a profound disenchantment with the current process of European integration, because it is seen as contradicting cosmopolitan claims, which are considered the core of the European project. Balibar stresses that EU policies regarding rights and citizenship lead to systematic practices of exclusion, because citizenship is not disconnected from nationality. This leads to the denial of certain basic rights based on a new kind of otherness, in the figure of non-UE citizens and illegal immigrants, which is tantamount to a form of 'European apartheid'.

It is important to emphasise that the second paradigm is the only one to take into account the originality of the European experience. The other two interpret the EU within the framework of a discussion on the future of democracy, rights and politics in a post-national world that goes beyond Europe. The first paradigm criticises the extension of individual rights and the destruction of the potential for collective political action and collective political identities, whereas the third paradigm, on the contrary, sees the extension of individual rights as positive but calls for a political community that is as inclusive as possible. Overall, compared to Germany, Scandinavian countries and even the UK, forms of European federalism or post-nationalism that put European integration at the core of a new stage of modernity, are singularly absent in contemporary French political thought (Lacroix \& Magnette 2008).

\section{3) Political debate on European integration since WWI: constraining the choice between pro- and anti-Europeanism}

Since WWI, most political and state actors in France have only considered Europe as an element of modernity in a very limited way. This is because modernity refers more to the nation's tradition and power than to the European project. Europe is also prevented from being a meaningful reference in France by the major parties' unanimous discourse about it.

\section{The privileged link between modernity and the French nation}

In the interwar years, there were French political figures who played an active role in fostering European unification. Aristide Briand, for example, is a name that remains deeply associated with pacifism and Europeanism. Briand was French Minister of Foreign Affairs 
several times, and also Prime Minister between 1925 and 1932; he was responsible for the French proposal made in 1929-1930 to institutionalise a European union. After WWII, prominent figures in the French state, such as Robert Schuman and Jean Monnet, also firmly advocated European unification, and committed themselves to the first steps of actual European integration in the 1950s. In the following decades, the involvement of French state actors persisted, with the exception of the 1960s when President Charles de Gaulle firmly defended French national independence, provoking political crises on the European political scene. From the 1950s through to the 1980s, European integration was linked to the ideas of French economic modernisation, peace and democratic values. However, the close association between modernity and the power and tradition of the French nation has prevailed over the European project throughout the whole of the $20^{\text {th }}$ century.

The role played by Europe in the modernisation of the French economy was emphasised in the first decades of European integration, from the 1950s to the 1980s, without much debate. The European Economic Community was seen as encouraging the opening of an economy (that had traditionally been quite protectionist) and the modernisation of key economic sectors, particularly agriculture (Muller 1984). Nevertheless, even during this period, Europe was considered to be just one factor in French economic modernisation; a central role was also granted to the state's economic planning. From the 1990s onwards, Europe was less and less represented in light of economic modernity. Faced with the rise of anti-liberalist movements, French state actors instead insisted on the importance of French public services, the welfare state and the necessity for the EU to take these institutions into account.

As for political modernity, state actors have repeatedly connected Europe with the ideas of peace, human rights and democracy. This was particularly true in the founding period of European integration (the 1950s), then again when the centre-right was in power (President V. Giscard d'Estaing, between 1974 and 1981), and again when the socialist left governed France in the 1980s. However, these political values are most often represented by French state actors as a national tradition, dating back to the French Revolution and republicanism, rather than as associated with the European project itself (Risse 2010).

Since WWII, state actors have also perceived Europe as a means of preserving France's international power. After the war, this power was seen as declining because of the French defeat in 1940, the new international influence of the United States and the Soviet Union, and the beginning of decolonisation (Bossuat 1996; du Réau 2001; du Réau and Frank 2002). Through European unification, France aimed for 'reincarnation' (Brzezinski 1997: 91) or 'extension' (Delanty 2005). French actors saw Europe as a way of pursuing national interests (by stimulating economic modernisation and growth) and extending national policies to the European level (Dulphy and Manigand 2006). Europe was then an instrument of national power and a place for the projection of French national identity through the creation a 'French' Europe, i.e. a Europe that would resemble France. This French understanding of the EU has been increasingly thrown into question by the loss of French influence in the domains of politics, culture and economics, as well as by the EU's enlargements eastwards. It has also been challenged by the culture of compromise that is a key feature of EU institutions and which has been considerably accentuated with the successive enlargements. However, this conception of Europe as a space for national influence still persists, hindering the Europeanization of French political identity and of public debate (Risse 2010). 


\section{French governing parties dodged the debate about Europe}

Since the beginning of the integration process, there has been division and contestation regarding Europe, both amongst French political elites and within political parties.

The Socialist Party may be seen as one of the political forces that most frequently supported European unification throughout the $20^{\text {th }}$ century. However, since 1945, this party has also been divided on European unification, at various points in time and for different reasons (Delwit 1995; Frank 2004b; Bergounioux \& Grunberg 2005). These reasons were sometimes related to political strategy; its alliance with the Communist Party, which was very critical towards Europe unification, prevented the PS from emphasising its European engagement during the 1970s. There were also disagreements concerning the relative importance of the nation, Europeanism and internationalism, and strong criticism of the liberal economic orientation of the EU, amongst the more left-wing factions within the Socialist Party. Generally speaking, until the 1980s, the French Socialist party was quite reticent about the reformism advocated by most European Left parties (Bergounioux \& Grunberg 2005). Nevertheless, over recent decades, and more specifically since they were elected in the early 80 s, leaders of the French Socialist Party have moved closer to the principles of social democracy and have significantly attenuated their criticism of the free market. Such reorientation has enabled the French Socialist Party to affirm its European engagement more strongly (Rorsher 1999). As a result, it has become less isolated in Europe, and along with parties on the European Left it has called for fairly incremental improvements to the EU's social dimension (Delwit 1995; Olivier 2005). In spite of this, some left-wing trends within the Socialist Party, as well as some prominent Socialist figures, continue to criticise the EU, denouncing both the undemocratic aspects of the EU's political system, and the EU's overly restrictive social and public services policies. During the referendum campaign in 2005, the split within the Socialist party on the issue of Europe was briefly acknowledged.

The French right was also marked by significant and longstanding divisions on Europe (Sauger 2005). The liberal trends on the right were favourable to European unification, at least in the form of a vast free market. The centre-right movement represented by the Christian-Democrats made the European cause a central element of its political identity, which remained stable throughout the $20^{\text {th }}$ century. Moreover, the Gaullist tradition saw Europe as a necessary means of preserving national influence and power, while demonstrating a profound attachment to national independence and sovereignty. In 1962, several ChristianDemocrat MPs resigned from government after de Gaulle's denunciation of the directions of European integration. In 1978, in a famous speech called the 'Appeal of Cochin', Gaullist Jacques Chirac stigmatised the centrist liberal President, Valéry Giscard d'Estaing, for his commitment to Europe. In this speech, he advocated France's independence from a Europe dominated by 'merchants'. The UMP (created in 2002 after a fusion between the Gaullist RPR and the centrist UDF), the dominant right-wing party currently in government, is less divided on this issue today. This is largely because of the conversion of Chirac to the European cause in the early 1990s (Startin 2005; Jardin 2001). 
On both the left and the right, political contestation of Europe provoked divisions within the major parties. French so called 'sovereigntist parties' emerged in the 1990s in the wake of the Maastricht Treaty. On the left of the political spectrum, Jean-Pierre Chevènement, former member of the Socialist Party, founded the 'Mouvement des citoyens' in 1993. On the right, Philippe de Villiers created the 'Mouvement pour la France' (MPF) in 1994, and Charles Pasqua founded the 'Rassemblement pour la France' (RPF) in 1999. While the ideologies of these parties differed, they all opposed the EU in the name of the defence of national sovereignty. They also identify democracy and social solidarity with the national framework only. The MPF and the RPF had some electoral success in the 1990s, but this was only temporary and mostly limited to European elections.

Clearly positioned as an anti-system party, the National Front has expressed a strong 'Europhobia' since the 1990s, repeatedly calling for France to leave the EU. This negative attitude towards Europe has not always characterised the FN's discourse, however. In the 1980s, Europe was seen as positive and identified with the Christian West, in opposition to migration threats coming from extra-European countries (Rozenberg 2007). The National Front has vigorously denounced immigration related to the creation of the Schengen area and to the enlargement of the EU, as well as the risk of the so-called 'Islamisation' of Europe with the potential entry of Turkey into the European Union. Moreover, in a context in which rightwing parties in government have widely supported European integration since the 1990s, the anti-European discourse of the National Front has also been a means of differentiating themselves from the rest of the right.

Political contestation of Europe also stems from what Rozenberg (2007) calls 'ruralist localism'. According to this perspective, the EU is criticised on behalf of the preservation of local particularities and traditions. The dominant representative of this kind of political contestation is the political party 'Chasse Pêche Nature \& Traditions' (CNPT), i.e. a political movement created in 1989 to protest against the EU's directives regarding hunting. In the 'rural localist' discourse, Europe is presented as a remote power that undermines the daily practices of ordinary citizens. The 'localist' discourse has spread amongst French political elites; all the more so as most French MPs cumulate local and national mandates and award much importance to their direct connection with their local voters (Rozenberg 2005).

Finally, since the mid-1990s, there has also been a new form of political contestation against Europe. Much less institutionalised, this challenge comes from heterogeneous organisations and takes the form of anti-liberalism. Anti-liberal parties and organisations call for 'another Europe'. They denounce the EU's liberal economic policies and the technocratic character of the EU's political system. This anti-liberal trend is represented by extreme-left parties: the Communist Party, the Trotskyites from the 'Ligue Communiste Révolutionnaire' (the LCR, which became recently the 'Nouveau Parti Anti-capitaliste', the NPA), as well as 'Lutte Ouvrière' (LO). It also attracts some members of the Green Party (although the majority of Greens are on the contrary very much Europhile) and some members of the Socialist Party. Civil society organisations, such as some of the major trade unions, foundations (the Copernic Foundation) and political associations (ATTAC), are also components of this anti-liberal movement. Anti-liberalism has developed since the mid-1990s and culminated during the referendum campaign on the European Constitutional Treaty in 2005. 
Considering the amount and diversity of political contestation of European integration, it is surprising to see how little place has been granted to this issue in public debate in recent decades. According to Bartolini (2001), the European issue attracts little public attention from political parties in European countries since it does not match the traditional political alliances between parties and, moreover, is a source of internal division for some of them. Such an analysis appears valid for France, but there are other reasons, which might be more specific to the French case, that may be added.

The Socialists Party and the major right-wing party, heir to the Gaullist tradition, have been governing the country for thirty years now. Both have been internally divided over the process of European integration, as we saw above. However, when in government, they have managed to maintain a European line since the early 1980s. They have framed the European project in terms of national interest, which prevents it from becoming a controversial issue. They have presented European integration in a unanimous way, emphasising the need to avoid isolating France in Europe and in the world; the advantage of a powerful Europe (including France) in confronting the U.S. and China; France's moral and legal engagements stemming from past agreements with other European countries, and so forth. This has led to schisms within governing parties, with Eurosceptics creating new opposing parties, as we saw above. The French debate on Europe has thus become a debate between pro- and antiEuropeans, structured along an opposition between major and minor parties. Governing parties have adopted consensual and low salience discourses on Europe, preventing public debate on the issue, whereas non-governing parties have tended to be openly Eurosceptic. The Green movement represents an exception in this respect - the new organisation, "Europe Ecologie", was quite successful in the 2008 regional elections. In fact, this movement is both Europhile and committed to promoting public debate in order to discuss critical opinions regarding the workings and future of the EU.

Clearly, the dynamics of political life in France have not produced a real public debate, based on alternative views of European integration ${ }^{2}$. The referendum campaign on the ratification of the European Constitutional Treaty in 2005, and its aftermath, is a good illustration of this. Citizens were asked to ratify a text, and attempts to discuss it tended to be interpreted as a rejection of Europe (Sauger, Brouard \& Grossman, 2007). Moreover, the 'no' expressed by French citizens was followed shortly after by the French Parliament's positive vote on a similar Treaty without contestation. Overall, significant debate about the political future of Europe has hardly occurred in France.

\section{Conclusion: Europe as a missed opportunity for a new step to modernity}

Since WWI, French discourses and projects regarding Europe have been based both on the aim to re-establish national dominance in the European and global contexts, and the ambition to unify Europe in a way that resembles France - or that at least does not challenge its

\footnotetext{
${ }^{2}$ One exception to this attitude, aside from the split within the Socialist Party on the referendum on the Constitutional Treaty, was the mobilisation in 2004 of some prominent figures within the UMP (such Alain Juppé and the future President Nicolas Sarkozy) against the entry of Turkey into the EU - they opposed President Chirac's position and dramatised the question (Sauger 2005).
} 
national traditions (in terms of public services, welfare policies, conceptions of democracy). The European project has, in fact, hardly been perceived as a way to achieve a new political modernity at all.

Instead of focusing on French actors' discourses on modernity and Europe, we can also consider the notion of modernity itself, as it is defined in recent political and social theory. In this light, can we say that the French public debate on European integration has contributed to a new step in modernity? As Delanty (2007) suggests, it is the 'self-transformative tendencies and self-conscious reflexivity' that is prominent in modernity, stemming from the existence of new dynamics and tensions. Another feature of modernity for theorists is the centrality of human agency in interpreting one's environment and in attempting to change it (Arnason 2003; Giddens 1994, 1998). Self-reflexivity and human agency result in a specific orientation towards the future, which is regarded as the sphere for improvement, innovation, and change. Building a new political community at the European level represents a significant opportunity for encouraging a new step in modernity. Indeed, it is a voluntary project that requires actors to break away from national path-dependency and to question previous arrangements. As such, it encourages new dynamics and self-reflexivity (Delanty 2005), as well as futureoriented attitudes (Abelès 1997, Belot 2000).

However, the way European integration has been framed in France over recent decades, has not taken advantage of this opportunity and as a result, the link between Europeanization and the key features of the modernity processes is minimal. The persistent official support for European integration on the part of the French government was gained at the expense of public debate about the kind of future the EU could offer. Moreover, French intellectuals have contributed little to this debate. As a result, French citizens have gained a new political community and have become accustomed to it, in a way that does not particularly meet the expectations of modernity that Europe integration could have raised. Citizens have come to accept Europe as an inevitable but stable reality, and to consider themselves European as a consequence of being French (Bozec 2010, Duchesne \& al 2010, Throssell 2010, Van Ingelgom 2010, Weil 2010). French identity is clearly the link between citizens and the European Union; they see the EU through the lens of the nation. European issues have no salience, they generate no strong feelings, no polarisation except in people who are politically sophisticated, and who are usually amongst the most educated. People who are interested in politics generally understand the influence of the EU on public policies, and thus care about the future of European integration; others do not, they show no interest and avoid argument or discussion of these themes. This lack of interest, which emerges clearly in qualitative research, contrasts with the popular Euroscepticism that scholars infer from survey data and have come to fear (see for instance Neil Fligstein's Euroclash 2008). But a careful reanalysis of Eurobarometer data shows that in France, neutral or indifferent attitudes towards European integration have increased more than negative attitudes, despite the strong politicisation of the campaign for the referendum on the Constitutional Treaty (Van Ingelgom, 2010). This indifference has increased most particularly among working class people and those not interested in politics (Duchesne \& Van Ingelgom 2009).

Two elements help explain most ordinary non-politically active citizens' lack of interest for European integration. Firstly, they believe that this process is already over: there is no use being "for" or "against" the EU; it is there and cannot be reversed. In this sense, European 
integration increases the diffuse popular feeling of being dominated by elites and politicians who make the decisions. Secondly, European issues have no salience because they are blurred by globalisation. Popular attitudes towards the EU are thus far from being organised around notions of agency and self-reflexivity. They do reflect strong tensions related to the role of their nation in a globalised world, but European integration is hardly an issue there (Duchesne \& al. 2010).

If Europe has the potential to be a new step towards modernity, the French route to European integration seems to have missed much of this opportunity. French public debate on Europe, both in the past and more recently, has rarely made explicit reference to a 'European modernity', nor can this debate be connected to the notion of modernity as defined in recent theoretical approaches. French debate on Europe allows little room for self-reflexivity and discussion of different conceptions of the European future; the issues are simply reduced to a single low-salience cleavage - being "pro" or "anti" the EU. In spite of the results of European referendums and the decreasing turn-out in European elections, the EU has been widely accepted by French citizens, but it has been accepted passively.

This missed opportunity is the result of many factors. The French route to modernity involved a national identity framed by the idea of France as one of the inventors of modernity itself, and by the vision a political community with the mission to disseminate universalistic values (inherited from the French Revolution) throughout the world. Hence, France's relationship to modernity has become backward-looking. French actors remain caught in this historical vision of modernity and cannot seem to imagine Europe offering a new one. Consequently, Europe appears to be a future imposed upon citizens without sufficient discussion or interpretation. 


\section{$\underline{\text { References }}$}

ABELES M. (1997) 'De l'Europe politique en particulier et de l'anthropologie en général', Cultures et Conflits, $\mathrm{n}^{\circ} 28$, pp. 33-58.

ARCHAMBAULT E. \& BOUMENDIL J. (1999) 'Dons et bénévolat en France', Revue internationale de l'Economie sociale, 77/1, pp. 17-30.

ARNASON J. (2003) Civilization in Dispute: Historical Questions and Theoretical Traditions, Leiden: Brill.

BACHOUD A., CUESTA J., TREBITSH M. (eds) (2009) Les intellectuels et l'Europe de 1945 à nos jours [actes du colloque international, Université de Salamanque, 16-18 octobre 1997], Paris: L'Harmattan.

BADIE B. \& BIRNBAUM P. (1979) Sociologie de l'Etat, Paris : Grasset.

BARBIER M. (2000) La modernité politique, Paris : Presses Universitaires de France.

BARTHELEMY M. (2000) Associations : un nouvel âge de la participation ?, Paris : Presses de Sciences Po. BARTOLINI S. (2001) 'La structure des clivages nationaux et la question de l'intégration dans l'Union européenne, Politique européenne, 4, pp. 15-45.

BAUBEROT J. (1990) Vers un nouveau pacte lä̈que ?, Paris : Seuil.

BAUBEROT J. (2006) 'Les seuils de laïcisation dans l'Europe latine et la recomposition du religieux dans la modernité tardive', in BASTIAN J.-P. (ed.) La modernité religieuse en perspective comparée. Europe latine-Amérique latine, Paris : Karthala, pp. 15-28.

BELOT C. (2000) L'Europe en citoyenneté. Jeunes Français et Britanniques dans le processus de légitimation de l'Union européenne, Political Science PhD Thesis, Université Pierre Mendès France/ IEP de Grenoble.

BERGOUNIOUX A. \& GRUNBERG G. (2005) L'ambition et le remords : les socialistes français et le pouvoir : 1905-2005, Paris : Fayard.

BIRNBAUM P. (1991) 'Nationalisme à la française', Pouvoirs, 57, pp. 55-69.

BIRNBAUM P. (1993) 'La conception française de l'Etat et sa construction historique', CFDT aujourd'hui, 110, pp. 5-19.

BIRNBAUM P. (2003) La France imaginée : déclin des rêves unitaires ?, Paris : Gallimard.

BLANCHARD P., BANCEL N., LEMAIRE S. (2005) La fracture coloniale : la société française au prisme de l'héritage colonial, Paris : La Découverte.

BOISVERT Y. (1996) Le monde postmoderne : analyse du discours sur la postmodernité, Paris : L'Harmattan.

BONNEVILLE G. (1961) Prophètes et témoins de l'Europe : essai sur l'idée d'Europe dans la littérature française de 1914 à nos jours, Leyden : Sythoff. 
BONNY Y. (2004) Sociologie du temps présent. Modernité avancée ou postmodernité ?, Paris : Armand Colin.

BOSSUAT G. (1996) L'Europe des Français, 1943-1959 : la IVe République aux sources de l'Europe communautaire, Paris : Publications de la Sorbonne.

BOZEC G. (2010) 'L'Europe au tableau noir. Comment les instituteurs enseignent-ils l'Union européenne aujourd'hui ?', Politique Européenne, 30, pp. 153-186.

BOZEC G. (2010) Les héritiers de la République. Eduquer à la citoyenneté à l'école dans la France d'aujourd'hui. Political Science PhD Dissertation, Sciences Po Paris.

BRZEZINSKI Z. (1997) Le grand échiquier, Paris: Bayard Editions.

BUSSIERE E., DUMOULIN M. (eds) (1998) Milieux économiques et intégration européenne en Europe occidentale au XXe siècle, Arras : Artois Presses Université.

CHABOT J.-L. (2005) Aux origines intellectuelles de l'Union européenne : l'idée d'Europe unie de 1919 à 1939, Grenoble : Presses Universitaires de Grenoble.

CHANET, J.- F. (1996) L'école républicaine et les petites patries, Paris : Aubier.

CITRON S. (2008) Le mythe national : l'histoire de France revisitée, Paris : Les Editions de l'Atelier / Les Editions Ouvrières.

DELANTY G. (2005) 'What does it mean to be a “European”?', Innovation, 18(1), pp. 11-22.

DELANTY G. (2007) 'Modernity', in RITZER G. (ed.) Blackwell Encyclopedia of Sociology, Blackwell reference Online (acceded 16 April 2010).

DELOYE Y. (1994) Ecole et citoyenneté. L’individualisme républicain de Jules Ferry à Vichy, Paris : Presses de la FNSP.

DELWIT P. (1995) Les partis socialistes et l'intégration européenne. France, GrandeBretagne, Belgique, Bruxelles : Editions de l'Université de Bruxelles.

DIEZ MEDRANO J. (2003) Framing Europe. Attitudes to European Integration in Germany, Spain and the United Kingdom, Princeton/Oxford: Princeton University Press.

DUCHESNE S. (1997) Citoyenneté à la française, Paris : Presses de Sciences Po.

DUCHESNE S. (2005) 'Identities, Nationalism, Citizenship and Republican ideology', in COLE A., LE GALES, P., LEVY J. (eds.) Developments in French Politics 3, ch. 16, New York: Palgrave Macmillan, pp. 230-244.

DUCHESNE S. \& VAN INGELGOM V. (2009) 'Persistent Working Class Disinterest in the EU: Rewording the Social Gap', Paper presented to the XIe Biennal Conference of the European Union Studies Association, Los Angeles, 23-25 ${ }^{\text {th }}$ of March 2009 (available at http://www.unc.edu/euce/eusa2009/papers/duchesne_05H.pdf). 
DUCHESNE et al. (2010) 'Europe between integration and globalisation social differences and national frames in the analysis of focus groups conducted in France, francophone Belgium and the United Kingdom', Politique européenne, 30, pp. 67-105.

DULPHY A., MANIGAND C. (2006) La France au risque de l'Europe, Paris : Armand Colin.

EISENSTADT S. (2000) 'Multiple modernities’, Daedalus, 129/1, pp. 1-29.

FLIGSTEIN N. (2008) Euroclash: the EU, European identity, and the future of Europe, Oxford: Oxford University Press.

FRANK R. (2004a) 'Changements identitaires et difficultés de "gouvernance"en Europe : une approche historique', in FRANK R., GREENSTEIN R. (eds) (2004) Gouvernance et identités en Europe, Bruxelles : Bruylant ; Paris : LGDJ.

FRANK R. (2004b) 'La gauche et l'Europe', in BECKER J.-J., CANDAR G. (eds) Histoire des gauches en France, Paris : La Découverte, pp. 452-472.

FREITAG M. (2002) L'oubli de la société : pour une théorie critique de la postmodernité, Rennes : Presses Universitaires de Rennes.

GIDDENS A. (1994) Les conséquences de la modernité, Paris: L’Harmattan.

GIDDENS A. (1998) 'The transition to late modernity', International Sociology, 13/1, pp. 117-133.

GIRAULT R. (1994) Identités et conscience européennes au XXe siècle, Paris : Hachette.

GREENFELD L. (1992) Nationalism : five roads to modernity, Cambridge, Mass.: Harvard University Press.

HABERMAS J. (1992) 'Citizenship and national identity: some reflections on the future of Europe, Praxis International, 12/1, pp. 1-19.

HABERMAS J. (2000) Après l'Etat-nation: une nouvelle constellation politique, Paris : Fayard.

HAYWARD J. (2007) Fragmented France - Two Centuries of Disputed Identity. Oxford: Oxford University Press.

HERVIEU-LEGER D. (2003) 'Pour une sociologie des "modernités religieuses multiples" : une autre approche de la "religion invisible" des sociétés européennes', Social Compass, 50/3, pp. 287-295.

HOBSBAWM E. J. (1992) Nations and nationalism since 1780: programme, myth, reality, Cambridge: Cambridge University Press.

JARDIN X. (2001) 'Les déchirements européens des gaullistes', Atelier électronique 'Les partis de droite en Europe’, www.afsp.msh-paris.fr. 
JAVEAU C. (2007) Les paradoxes de la postmodernité, Paris : Presses Universitaires de France.

KRULIC B. (2007) 'L'universalisme républicain', Cahiers Français [special issue 'L'identité nationale'], 342, pp. 27-31.

LABORDE C. (2010) Français, encore un effort pour être républicains !, Paris : Seuil.

LACROIX J. (2008) La pensée française à l'épreuve de l'Europe, Paris : Grasset.

LACROIX J. \& MAGNETTE P. (2008) 'Théorie politique', in BELOT C., MAGNETTE P., SAURUGGER S. (eds.) Science politique de l'Union européenne, Paris : Economica.

LIPOVETSKY G. (with CHARLES S.) (2004) Les temps hypermodernes, Paris: Grasset.

LYOTARD J.-F. (1979) La condition postmoderne: rapport sur le savoir, Paris: Editions de Minuit.

MAFFESOLI M. (2000) 'De la “postmédiévalité" à la postmodernité', Réseaux, 88/89/90 [special issue : 'Modernité et postmodernité'].

MAYEUR J.-M. (1997) La question laïque. XIX $X^{e}-X X^{e}$ siècle, Paris : Fayard.

MULLER P. (1984) Le technocrate et le paysan: essai sur la politique française de modernisation de l'agriculture: de 1945 à nos jours, Paris : Ed. ouvrières.

MÜLLER J.-W. (2006) 'Julien Benda's AntiPassionate Europe', in European Journal of Political Theory, 5/2, pp. 125-137.

NOIRIEL G. (2006) Le Creuset français. Histoire de l'immigration, XIX $-X X^{e}$ siècle, Paris : Seuil.

NOIRIEL G. (2007) Immigration, antisémitisme et racisme en France, XIX $X^{e}-X X^{e}$ siècle. Discours publics, humiliations privées, Paris : Fayard.

OLIVIER L. (2005) 'Le Parti socialiste et l'européanisation de l'espace de confrontation politique : le clivage national à l'épreuve du clivage sur l'intégration européenne', Politique européenne, 16, pp. 157-184.

PERES H. (1994) 'Le village dans la nation française sous la Troisième République. Une configuration cumulative de l'identité', in MARTIN D.-C. (ed.) Cartes d'identité. Comment dit-on nous en politique, Paris : Presses de la FNSP, pp. 209-223.

de PUYMEGE G. (1997) Les mouvements européens, Arles : Actes Sud.

du Réau E. (2001) L'Idée d'Europe au XXe siècle: des mythes aux réalités, Bruxelles: Complexe.

du Réau E., FRANK R. (eds) (2002) Dynamiques européennes, nouvel espace, nouveaux acteurs : 1960-1981, Paris: Publications de la Sorbonne.

RISSE T. (2010) A community of Europeans? Transnational Identities and Public Spheres, Ithaca: Cornell University Press. 
ROSANVALLON P. (1992) Le sacre du citoyen : histoire du suffrage universel en France, Paris : Gallimard.

ROSCHER K. (1999) 'Transforming the State or Diluting the Nation? Ideas, Interests and French Discourses on European Integration', Paper presented at the ECSA Sixth Biennial Institutional Conference, Pittsburgh, Pennsylvania, June 2-5 ${ }^{\text {th }}$.

ROZENBERG O. (2005) Le Parlement français et l'Union européenne (1993-2005) : l'Europe saisie par les rôles parlementaires, Political Science PhD Dissertation, Sciences Po Paris.

ROZENBERG O. (2007) 'La faute à Rousseau ? Les conditions d'activation de quatre idéologies critiques de la construction européenne en France', in LACROIX J. \& COMAN R. (eds.) Résister à l'Europe: figures des oppositions au modèle européen, Bruxelles: Université de Bruxelles.

SAUGER N. (2005) 'Sur la mutation contemporaine des structures de la compétition partisane en France: les partis de droite face à l'intégration européenne', Politique européenne, $2005 / 2, \mathrm{n}^{\circ} 16$.

SAUGER N., BROUARD S., GROSSMAN E. (2007) Les Français contre l'Europe ? Les sens du référendum du 29 mai 2005, Paris : Presses de Sciences Po, 2007.

SCHNAPPER D. (1994) La communauté des citoyens: sur l'idée moderne de nation, Paris: Gallimard.

SCHNAPPER D. (2000) Qu'est-ce que la citoyenneté ?, Paris : Gallimard.

SIMONET, M. (1998) 'Le bénévole et le volunteer ; ce que traduire veut dire', Revue du MAUSS, Une seule solution, l'association ? Socio-économie du fait associatif, ${ }^{\circ} 11,1998, \mathrm{pp}$. 57-64.

STARTIN N. (2005) 'Maastricht, Amsterdam and beyond: the troubled evolution of the French right', in DRAKE H. (ed.) French Relations with the European Union, London and New York: Routledge.

THIESSE A.-M. (2010) 'L’histoire de France au musée', Raisons Politiques, n³7, pp. 103117.

THROSSELL K. (2010) 'One thing leads to another: European and National Identities in French school children', Politique Européenne, 30, pp. 131-152.

VAN INGELGOM V. (2010) Intégrer l'Indifférence: Une approche comparative, qualitative et quantitative, de la légitimité de l'intégration européenne, Political Science $\mathrm{PhD}$ Dissertation, Université catholique de Louvain-la-Neuve/Sciences Po Paris.

WEBER E. (1983) La fin des terroirs : la modernisation de la France rurale : 1870-1914, Paris : Fayard.

WEILL P.-E. (2010) “"Plutôt l'UEFA que l'UE !” (dés-)enchantement de l'identification à l'Europe des jeunes de milieux populaires issus de l'immigration', Politique européenne, 30, pp. 107-130. 
WINOCK M. (2004) Nationalisme, antisémitisme et fascisme en France, Paris : Seuil.

\section{Summary :}

In northern European countries, France included, the route to modernity was paved with nationalism, and that along the way, these nations were established as the secular, democratic, industrialised (and eventually post industrialised) welfare states we know today. However, each of these countries took their own route to modernity, and experienced the tensions inherent in this process in their own way. Moreover, we know from previous work that European integration is "framed" by national culture; it is thus perceived differently in different European countrie. Has the specificity of France's route to modernity had an impact on the way the French have perceived Europe? More specifically, has it affected European integration and the possible generation of a corresponding identity?

Addressing these questions means providing a brief overview of the specificities of the French route to modernity, with an emphasis on the tensions that it was born out of. We then move on to an account of the limited and ambiguous ways in which intellectuals have explicitly referred to modernity in their discussions of Europe over the last century. We thus focus on the role of political debate, showing how a range of issues, positions and divisions have been reduced to a single choice between being "pro" or "anti" Europe. We conclude by addressing the consequences of this limited debate concerning France's European future, its impact on French citizens' attitudes towards their new political community, and the "missed opportunity" that this lack of debate represents. 